\title{
Kritikus állapotú, légzéstámogatást igénylő COVID-19-fertőzött beteg ellátásának gyakorlati szempontjai
}

\author{
Végh Tamás dr. - László István dr. - Juhász Marianna dr. \\ Berhés Mariann dr. - Fábián Ákos dr. - Koszta György dr. \\ Molnár Csilla dr. - Fülesdi Béla dr.
}

Debreceni Egyetem, Általános Orvostudományi Kar, Klinikai Központ, Aneszteziológiai és Intenzív Terápiás Klinika, Debrecen

\begin{abstract}
2019 decemberében egy új típusú pneumoniajárvány kitöréséről számoltak be a kínai Wuhan városából, melynek kórokozója egy új koronavírus volt. A kezdetben állatról emberre terjedő betegség késóbb emberről emberre is terjedt, világjárványt okozva. A vírus okozta betegség (COVID-19) a tünetmentestől az enyhe tünetekkel járón keresztül a súlyos, légzési elégtelenséggel, intenzív osztályos ellátást igénylő spektrumon keresztül változatos formában megjelenhet. Ez utóbbi betegcsoport ellátása jelentős terhet ró az egészségügyre. Ezen összefoglaló célja az intenzív ellátást és légzéstámogatást/gépi lélegeztetést igénylő betegek ellátásának gyakorlati aspektusait hivatott bemutatni. Orv Hetil. 2020; 161(17): 678-684
\end{abstract}

Kulcsszavak: COVID-19-fertózött beteg, légzési elégtelenség, légzéstámogatás, intenzív terápia, gépi lélegeztetés

\section{Practical aspects of intensive care for critically ill COVID-19 patients requiring respiratory support}

In December 2019, a novel outbreak of pneumonia was reported in Wuhan city, China. Initially, the zoonitic infec tion spread from human to human, causing a pandemic. This viral disease (COVID-19) can appear in a variety of forms, from asymptomatic through the spectrum of mild symptoms to severe respiratory failure, requiring intensive care. Caring for this latter group of patients puts a significant burden on health care. The purpose of this summary is to present the practical aspects of intensive care for patients requiring respiratory support and mechanical ventilation.

Keywords: COVID-19 patients, intensive care, respiratory insufficiency, respiratory support, mechanical ventilation

Végh T, László I, Juhász M, Berhés M, Fábián Á, Koszta Gy, Molnár Cs, Fülesdi B. [Practical aspects of intensive care for critically ill COVID-19 patients requiring respiratory support]. Orv Hetil. 2020; 161(17): 678-684.

(Beérkezett: 2020. március 27.; elfogadva: 2020. március 30.)

\section{Rövidítések}

$\mathrm{APL}=$ (adjustable pressure-limiting $)$ állítható nyomásszabályozó; ARDS = (acute respiratory distresss syndrome) heveny légzési distressz szindróma; $\mathrm{BAL}=$ bronchoalveolaris lavage; $\mathrm{CO}$ $=($ cardiac output $)$ perctérfogat; COVID-19 = (coronavirus disease 2019) koronavírus-betegség 2019; CPAP = (continuous positive airway pressure) folyamatos pozitív légúti nyomás; $\mathrm{CT}=$ (computed tomography) számítógépes tomográfia; $\mathrm{DO}_{2}=$ (delivered oxygen) szállított, a szövetekig eljutó oxigén; $\mathrm{ECMO}=($ extracorporeal membrane oxygenation $)$ extracorporalis membránoxigenizáció; $\mathrm{EtCO}_{2}=($ end-tidal carbon diox- ide) kilégzésvégi szén-dioxid (koncentrációja); FEU = (fibrinogen-equivalent unit) fibrinogénekvivalens egység; $\mathrm{FiO}_{2}=$ (fraction of inspired oxygen) a belégzett oxigén koncentrációja; HEPA = (high-efficiency particulate air) nagy hatékonyságú részecskeszürö; HFNO = (high-flow nasal oxygen) magas áramlású, orron keresztül alkalmazott oxigénterápia; HME = (heat and moisture exchanger) hö- és nedvességcserélö; $\mathrm{LMWH}=($ low-molecular-weight heparin $)$ alacsony molekulasúlyú heparin; MAN/SPONT = kézi lélegeztetés/spontán légzés; NIV = (non-invasive ventilation) noninvazív lélegeztetés; $\mathrm{NO}=$ nitrogén-monoxid $\mathrm{PaCO}_{2}=($ partial pressure of car- 
bon dioxide in arterial blood) a szén-dioxid parciális nyomása az artériás vérben; $\mathrm{PaO}_{2}=$ (partial pressure of oxygen in arterial blood) az oxigén parciális nyomása az artériás vérben; PBW $=($ predicted body weight $)$ ideális testtömeg; PEEP $=($ positive end-expiratory pressure) pozitív kilégzésvégi nyomás; $\mathrm{pH}=$ pondus hidrogenii; Pplat $=$ (plateau pressure) platónyomás; $\mathrm{SaO}_{2}=$ oxigénszaturáció; $\mathrm{ScvO}_{2}=$ centrális vénás oxigénszaturáció

\section{Légzéstámogatás és gépi lélegeztetés}

- Ha a beteg nem reagál a standard oxigénterápiára, az súlyos hypoxaemiás légzési elégtelenségként kezelendő, és fel kell készülni az intubációra és a gépi lélegeztetésre, mivel a betegeknek még magas áramlású oxigén (10-15 1/perc) mellett is fokozott légzési munkájuk és hypoxaemiájuk lehet.

- Az endotrachealis intubációt gyakorlott személynek kell végeznie, minimálisra csökkentve az aeroszolképződést. ARDS-es, elhízott, terhes betegek és gyerekek hamar deszaturálódnak intubálás alatt, ezért 5 percig tartó 100\%, arcmaszkon keresztül adott oxigénnel történő preoxigenizálás szükséges. Rapid szekvenciális intubálás javasolt (1. ábra).

- Gépi lélegeztetés során alacsony légzési térfogat (4-8 $\mathrm{ml} / \mathrm{kg}$ PBW) és alacsony légúti nyomások alkalmazása javasolt (Pplat $<30$ vízcm). Ez az ajánlás nemcsak ARDS-re, hanem sepsis indukálta légzési elégtelenségre is vonatkozik (2. ábra).

- A kezdeti légzési térfogat $6 \mathrm{ml} / \mathrm{kg}$ PBW, mely szükség esetén emelhetô $8 \mathrm{ml} / \mathrm{kg} \mathrm{PBW-ig} \mathrm{is} \mathrm{(diszszink-}$ ronitás, $\mathrm{pH}<7,15)$ :
PBW kg $=([$ magasság $\mathrm{cm}-152,4] \times 0,9)+50$ (férfiaknál $)=([$ magasság cm $-152,4] \times 0,9)+45,5$ (nőknél)

- Permisszív hypercapnia megengedhető.

- Mély szedálás szükséges lehet a megfelelő lélegeztetéshez.

- Gyermekek esetén alacsony platónyomást (<28 vízcm) ajánlott tartani, emellett alacsonyabb $\mathrm{pH}$ is megengedhető $(7,15-7,3)$. A légzési térfogatot a betegség súlyosságához kell igazítani: 3-6 ml/kg PBW alacsony compliance esetén, és $5-8 \mathrm{ml} / \mathrm{kg}$ PBW, amennyiben a compliance jobban megtartott.

- Felnőttek esetén, amennyiben megoldható, naponta 12-16 óra, hason fekvö helyzetben történó lélegeztetés javasolt. Terheseknél kevés bizonyíték áll rendelkezésre a hason fekve történő lélegeztetésről. Ebben az esetben az oldalt fekvő helyzetben történő lélegeztetés megfontolandó.

- Közepesen súlyos és súlyos ARDS-ben magas PEEP használata javasolt.

- A PEEP-titrálás során mindig mérlegeljük a lehetséges előnyöket (az atelectrauma csökkentése, az alveolaris 'recruitment' [toborzás] révén az oxigenizáció javulása) és a rizikófaktorokat (az alveolusok túlfeszülése a belégzés végén, mely további tüdőkárosodáshoz és magasabb pulmonalis vascularis ellenálláshoz vezethet).

- Fiatal gyermekekben maximálisan 15 vízcm PEEP alkalmazása javasolt.

- Célzottan 'driving pressure' vezérelte lélegeztetésre vonatkozó randomizált, kontrollált tanulmányok

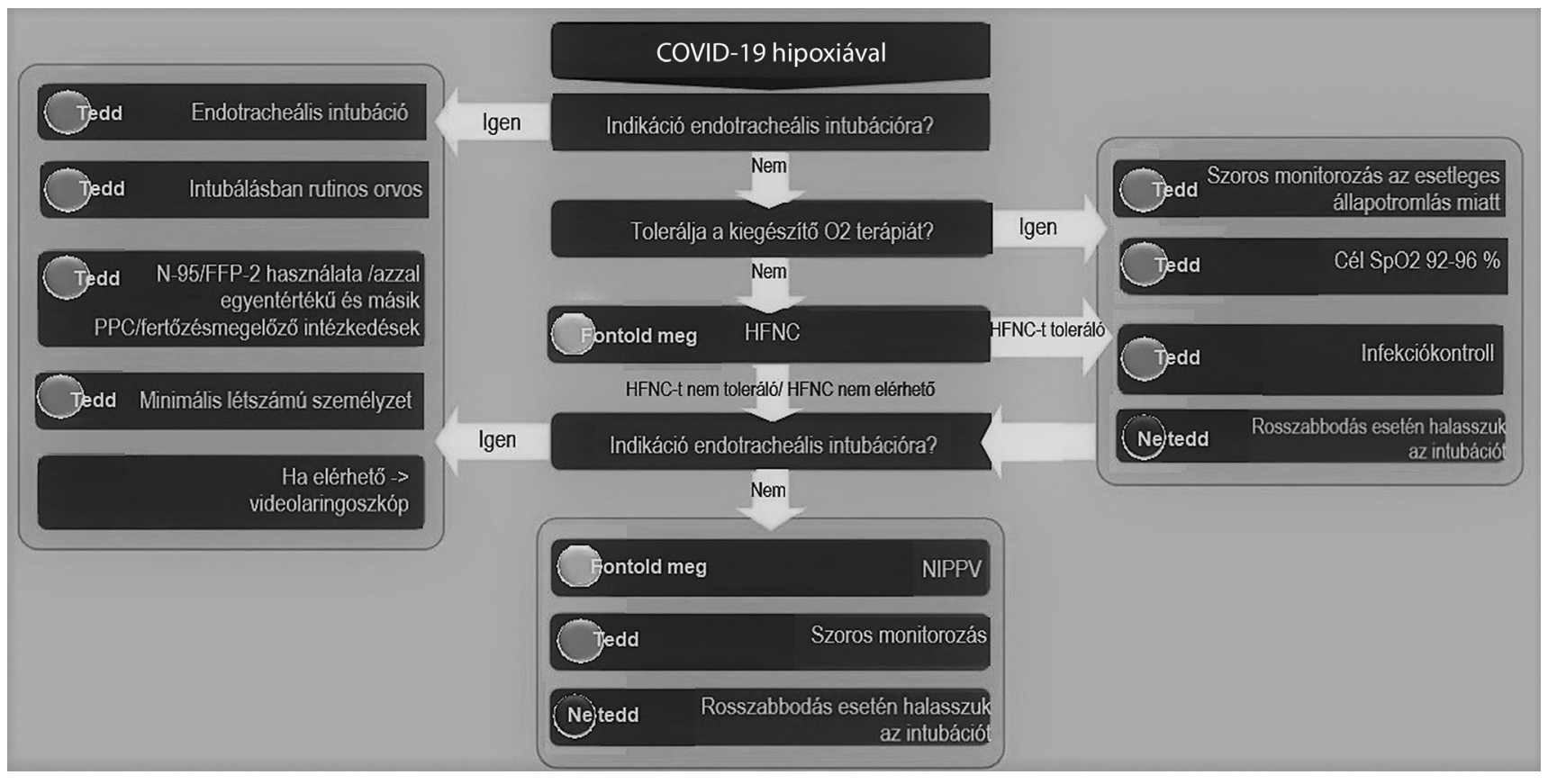

1. ábra | Légzéstámogatást igénylő COVID-19-fertőzött beteg kezdeti ellátása ([4] alapján)

COVID-19 = koronavírus-betegség 2019; FFP2 = részecskeszúrő félálarc; HFNC = magas áramlású orrkanül; NIPPV = noninvazív pozitív nyomású lélegeztetés; $\mathrm{PEEP}=$ pozitív végkilégzési nyomás; $\mathrm{SPO}_{2}=$ perifériás kapilláris vér oxigéntelítettség 


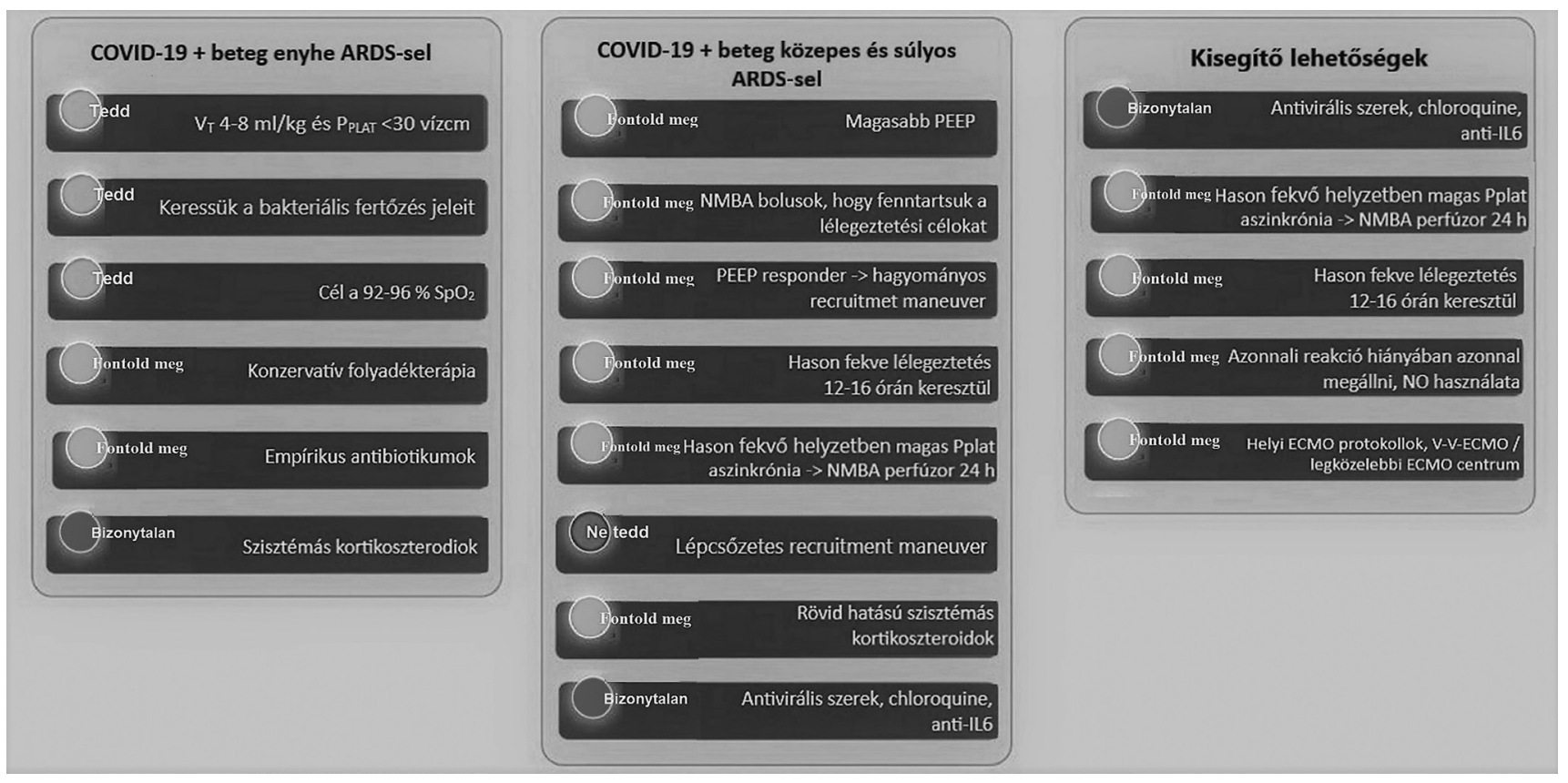

2. ábra

Gépi lélegeztetést igénylő COVID-19-fertőzött beteg ellátása ([4] alapján)

anti-IL6 = anti-interleukin-6; ARDS = heveny légzési distressz szindróma; COVID-19 = koronavírus-betegség 2019; ECMO = extracorporalis membránoxigenizáció; NMBA = neuromascular blocking agent: izomleraxáns; $\mathrm{NO}=$ nitrogén-monoxid; PEEP = pozitív kilégzésvégi nyomás; Pplat = platónyomás; $\mathrm{SpO}_{2}=$ perifériás kapilláris vér oxigéntelítettség; $\mathrm{VV}$ ECMO = venovenosus $\mathrm{ECMO}$

eredményei jelenleg nem állnak rendelkezésre. A jelenleg rendelkezésre álló tapasztalatok szerint alacsony 'driving pressure' alkalmazása javasolt (13 vízcm alatt), mivel a tüdőcompliance általában jó, így a platónyomás (Pplat) általában kevesebb, mint 25-27 vízcm (a tüdők könnyen lélegeztethetők).

- Mind a magasabb PEEP-értékek (13-15 vízcm), mind az alveolustoborzó manöverek alkalmazása ajánlott, ezeket azonban a betegeknél egyedileg kell alkalmazni. Mindezek mellett szükséges a betegek monitorozása arra vonatkozóan, hogy reagálnak-e az alveolustoborzásra, illetve a PEEP emelésére, az esetleges nemkívánatos hatások elkerülése érdekében.

- Amennyiben alveolustoborzásra kerül sor, a lépcsőzetes (incremental) PEEP-emeléses eljárás nem javasolt.

- A PEEP titrálása során a centrális vénás oxigénszaturáció $\left(\mathrm{ScvO}_{2}\right)$ mérése is ajánlott. Amennyiben a PEEP emelése során az oxigenizáció javul, de a $\mathrm{ScvO}_{2}$ nem változik vagy csökken, az oxigenizáció javulása a perctérfogat csökkenésének eredménye, mivel a PEEP emelése nem nyit meg újabb alveolusokat, ellenben a perctérfogatot csökkenti. A PEEP-emelés hatására bekövetkező oxigenizációjavulás tehát egyidejű a $\mathrm{ScvO}_{2}$ csökkenéssel romló hemodinamikát jelez [14].

- Tapasztalatok alapján a gépi lélegeztetésre szoruló COVID-19 fertőzött betegetek két nagy csoportba lehet osztani:
- 4H típus: high elastance, high right-to-left shunt, high lung weight, high recruitability (magas elasztansz, magas intrapulmonalis sönt, magas tüdősúly, jól reagál az alveolus toborzásra).

- 4L típus: low elastance, low ventilation/perfusion ratio, low lung weight, low recruitability (alacsony elasztansz, alacsony ventiláció/perfúzió arány, alacsony tüdősúly, rosszul reagál az alveolus toborzásra).

- A két típust CT vizsgálattal, klinikai jelek és légzésmechanikai paraméterek alapján lehet elkülöníteni egymástól. Nagyon fontos tehát felismerni azokat a magas tüdőcompliance-ű, virális pneumoniában szenvedő betegeket, akiknél megváltozott a hypoxiás pulmonalis vasoconstrictio (4L típus). Ilyen betegeknél nem szükséges magas PEEP-et alkalmazni, hiszen a tüdejük légtartó, a problémát a ventiláció/perfúzió arányának megváltozása okozza. Elegendő 8-10 vízcm PEEP és magasabb, $8 \mathrm{ml} / \mathrm{kg}$ PBW légzési térfogat alkalmazása. Mivel az alveolusok toborozhatósága alacsony, a magasabb PEEP és recruitment manőver alkalmazása barotraumához és a keringés összeomlásához vezethet. A $4 \mathrm{H}$ típust a súlyos ARDS-nek megfelelően kell lélegeztetni és kezelni.

- A 16 vízcm feletti PEEP-alkalmazás jelentős mértékben ronthatja a jobb szívfél funkcióját, és a keringés fenntartásához jelentős mennyiségű folyadékbevitelre van szükség.

- A magas PEEP miatti keringésromlás akut vesekárosodáshoz vezethet. Célszerű magas PEEP esetén szív- 
ultrahangvizsgálattal monitorozni a jobb szívfél állapotát.

- $\mathrm{Az} \mathrm{EtCO}_{2} / \mathrm{PaCO}_{2}$ arány monitorizálása nagy segítség lehet az intrapulmonalis sönt nagyságának felmérésében (ez általában 50\% körül van ilyen betegekben). Minél távolabb van az arány az l-es értéktől, annál nagyobb a sönt mértéke [3-14].

- Közepesen súlyos és súlyos ARDS-es betegek $\left(\mathrm{PaO}_{2} /\right.$ $\mathrm{FiO}_{2}<150$ ) lélegeztetése során a folyamatos izomrelaxáció rutinszerü alkalmazása nem ajánlott. Szükség esetén bolus izomrelaxáns adása javasolt. A folyamatos neuromuscularis blokád mind felnőtteknél, mind gyermekeknél az alábbi esetekben fontolandó meg (max. 48 óráig):

- beteg-gép diszszinkronizáció a szedálás ellenére (a megfelelő légzéstérfogat nem érhető el);

- visszatérő hypoxaemia vagy hypercapnia esetén [15, 16].

- Kerülendő a beteg gépről való dekonnektálása, mivel így a PEEP hatása elvész, és atelectasia alakulhat ki.

- Zárt rendszerú szívó használata javasolt.

- Amikor a dekonnektálás feltétlenül szükséges (például transzport-lélegeztetőgépre való áttéréskor), a tubus peannal történő lefogása/elszorítása szükséges. Dekonnekció során először az endotracheális tubust belégzésben lefogjuk, majd a lélegeztetőgépet „Készenlét” módba állítjuk. Amikor a lélegeztetés leállt, a tubust dekonnektálhatjuk a lélegeztetőgépről. Miután elvégeztük a beavatkozást, a lélegeztetőgépet a tubushoz csatlakoztatjuk, elindítjuk a lélegeztetést, majd ezt követően engedjük fel a tubus lefogását. Amennyiben a tubus pozícióját korrigáljuk, a tubus lefogását kilégzésben végezzük el, hogy a tüdőkben maradt levegő a leengedett mandzsetta mellett ne sodorjon magával vírus-partikulumokat a légutakból.

- A légutak leszívása során a szedáció mélyítése szükséges. Bronchoszkópos légúttoilette esetén viszont izomrelaxáció használata javasolt.

- A NIV és a HFNO rutinszerú alkalmazása intenzív osztályon a rendelkezésre álló adatok és tapasztalatok alapján nem ajánlott.

- Noninvazív lélegeztetés, magas áramlású, orron keresztül alkalmazott oxigénterápia (HFNO) csak válogatott betegeknél, speciális esetekben végezhető. Használata nagy körültekintést igényel, mivel a fertőzés terjedését nagyban elősegítheti az aeroszolképződés miatt, valamint a tapasztalatok szerint a kezdetben NIV-lélegeztetésben részesült betegeknél a későbbiekben lélegeztetési nehézség lépett fel. Ha mégis NIV mellett döntünk, a beteget azonnal intubálni kell, ha 15-30 percnyi CPAP alkalmazása során, 60\%-os $\mathrm{FiO}_{2}$ mellett:

- $\mathrm{SaO}_{2}$ kevesebb, mint 95\%;

- vagy a $\mathrm{PaO}_{2} / \mathrm{FiO}_{2}$ aránya kevesebb, mint 200;

- és/vagy a légzésszám 25-30/percnél magasabb.
- Azoknál a betegeknél, akiknél az invazív lélegeztetés nem eredményes, a tüdőprotektív lélegeztetés ellenére visszatérő hypoxaemiájuk van, az extracorporalis membránoxigenizáció(ECMO) alkalmazása megfontolandó lehet. Az ECMO-kezelés szükségessége nagyon ritka.

- Tapasztalatok alapján azon betegeknél, akiknél a pulmonalis compliance magasabb, mint 45-50 1/vízcm, kevesebb, mint 10 vízcm PEEP mellett az inbalációs nitrogén-monoxid alkalmazása megfontolandó, de a NO rutinszerú adása nem javasolt.

- Szöveti hipoperfúzió jeleit nem mutató ARDS-es betegekben konzervatív folyadékterápia javasolt.

- A tüdőfolyamat monitorozására elsősorban mellkasröntgen- és tüdőultrahang-vizsgálat javasolt. A mellkasi CT e célból való alkalmazása nem indokolt.

- Bronchoalveolaris lavage (BAL) a felvételkor javasolt, illetve ezt követően hetente egyszer. A tamponpálcával vett orr/garat tenyésztések negatívak lehetnek, miközben a BAL pozitív eredményt mutathat $[3,17-$ $18]$.

\section{A szövődmények megelőzése}

- A lélegeztetési napok számának csökkentése:

- leszoktatási protokollok alkalmazása, melyek magukban foglalják a spontán légzésre való képesség naponta elvégzett felmérését;

- a folyamatos vagy intermittáló szedálás minimalizálása, meghatározva a specifikus végpontokat (felületes szedálás, amennyiben az nem kontraindikált) vagy a folyamatos szedálás naponkénti megszakítása.

- A lélegeztetögéphez társult pneumonia incidenciájának csökkentése:

- orotrachealis intubáció ajánlott a nasotrachealis intubáció helyett felnőttekben és serdülőkben;

- félülő helyzet alkalmazása (30-45-ban megemelt felsőtest);

- zárt rendszerú szívó alkalmazása, a szívó és a páracsapda rendszeres cseréjével;

- minden betegnél új légzőkör alkalmazása; a légzőkört csak szennyeződés vagy sérülés esetén kell cserélni - rutinszerü cseréje a lélegeztetés során nem szükséges;

- a hő- és párafilterek cseréje szennyeződés esetén vagy minden $5-7$. napon.

- A vénás thromboembolia incidenciájának csökkentése: gyógyszeres profilaxis javasolt (LMWH vagy egyéb heparin adásával felnőttekben és serdülőkben, ha kontraindikáció nem áll fenn). Ellenjavallat esetén mechanikus profilaxis javasolt (intermittáló pneumatikus kompressziós harisnya).

- Óvatos folyadékterápia. A vérnyomás emelésére elsődlegesen noradrenalin javasolt, mely adrenalin, vazopresszin és dobutamin adásával kiegészíthető. Folyadékpótlásra krisztalloidoldat javasolt. Hypotoniás 
krisztalloidoldatok, albumin, keményítő- és zselatinoldatok rutinszerü használata nem javasolt.

- A kortikoszteroidok adása nem javasolt, kivéve, ha a noradrenalin dózisa meghaladja a $0,7 \mu \mathrm{g} / \mathrm{kg} /$ perc dózist. Ebben az esetben $4 \times 50 \mathrm{mg}$ hidrokortizon adása javasolt lehet (de legfeljebb néhány napig) [18, 19].

- Különös figyelmet kell fordítani a $D$-dimer-értékekre. Naponta 1-2× célszerú mérni. Amennyiben a D-dimer értéke magasabb, heparin-antikoaguláció szükséges.

- A katéterbez kapcsolódó véráramfertözések incidenciájának csökkentése:

- csekklista alkalmazása és a sterilitás szabályainak betartása szükséges;

- a katéter mielőbbi eltávolítása, amennyiben nincs rá szükség.

- A felfekvések incidenciájának csökkentése:

- a betegeket kétóránként forgatni kell.

- A stressulcus és a gastrointestinalis vérzés incidenciájának csökkentése:

- korai enteralis táplálás elkezdése (24-48 órával a felvételt követően);

- $\mathrm{H}_{2}$-receptor-blokkolók vagy protonpumpagátlók alkalmazása gastrointestinalis vérzés rizikója esetén; rizikófaktorok:

- tartós gépi lélegeztetés ( $\geq 48$ óra),

- coagulopathia,

- vesepótló kezelés,

- májbetegség,

- többszörös kísérő betegségek,

- magas szervelégtelenségi pont.

- Az intenzív terápia okozta izomgyengeség incidenciájának csökkentése:

- a lehető leghamarabb aktív mobilizálás.

- A várandósok ellátása:

- kevés adat áll rendelkezésre ezen a területen a kimenetelt illetően;

- nincs bizonyíték arra vonatkozóan, hogy a terhesek más tüneteket produkálnának, mint a nem terhesek;

- arra sincs bizonyíték, hogy a fertőzés anyáról magzatra terjedne;

- a COVID-19-fertőzött terhesek ellátása izolált szülészeti-nőgyógyászati centrumokban javasolt [3-5].

\section{Speciális lélegeztetési megfontolások}

Az intenzív osztályok és a rendelkezésre álló lélegeztetőgépek kapacitása véges. A legvégső esetben szülkség lehet a mütőben használt altatógépek bevonásáva is a COVID-19-fertôzött betegek intenziv osztályos lélegeztetésére. A következőkben az erre az esetre vonatkozó gyakorlati tanácsokat mutatjuk be.

- Lehetőség szerint legalább alapszintű oktatás szükséges az intenzív osztályos orvosok, nővérek részére.

- Egy tapasztalt aneszteziológusnak vagy legalább aneszteziológusasszisztensnek folyamatosan rendelkezésre kell állnia, akit lélegeztetési probléma vagy az altatógép meghibásodása esetén azonnal értesíteni kell.

- Amennyiben lehetséges, az altatógépeket csak kontrollált lélegeztetési módban használjuk.

- Minden, anesztetikum adagolására alkalmas eszközt (vaporizátorok, DIVA-egységek) el kell távolítani a gépról.

- Váratlan múködészavar esetén kézi, ballonos lélegeztetésre kell áttérni. A MAN/SPONT üzemmódot ne használjuk, vagy csak tapasztalt orvos jelenlétében, mivel ez az üzemmód nem azonos az intenzív osztályos lélegeztetőgépek spontán légzéses üzemmódjaival.

- Az altatásban tapasztalatlan felhasználók arra számíthatnak, hogy a gépi lélegeztetés közben az APL-szelep a légúti nyomást is korlátozza. Az APL-szelep azonban nem befolyásolja a gépi lélegeztetést. A szelep csak a MAN/SPONT üzemmódban aktív. A lélegeztető meghibásodása esetén a MAN/SPONT automatikusan életbe lép, és a frissgáz-áramlás biztosítja, hogy a légúti nyomás elérje az APL-beállítást. Ezért az APL-szelepet gépi lélegeztetés esetén is a beteg igényeinek megfelelő értékre kell állítani. Az APL-szelepnek a kívánt PEEP-szintre (vagy egyéb esetben SPONT-értékre, amelynek értéke nulla) történő beállítása megakadályozza, hogy a lélegeztető meghibásodása esetén a beteg túlzott légúti nyomásnak legyen kitéve. A rendszer ellenőrzésekor az APL-szelepet egy viszonylag magas értékre kell állítani. Ezért a felhasználónak gépi lélegeztetés esetén is csökkentenie kell ezt az értéket.

- Az altatógépek riasztási rendszere mútői körülményekre van tervezve és beállítva:

- a riasztás abbamarad, ha a riasztást kiváltó állapot/ körülmény megszúnik;

- a monitorok nem csatlakoztathatók központi monitorhoz, így a riasztások is csak helyben észlelhetők, ezért

- a riasztási hangerőt maximálisra, 100\%-ra kell állítani,

- az altatógépeket úgy tervezték, hogy a kezelőszemélyzet maximum négyméteres körben tartózkodik, ezért fontos az altatógéppel lélegeztetett beteg közvetlen, szoros megfigyelése;

- az intenzív osztályos lélegeztetőgépek magas áramlású, nyílt rendszerek, míg az altatógépek alacsony áramlású, visszalégző rendszerek, ezért a 'soda lime'-ot folyamatosan ellenőrizni kell - amennyiben a 'soda lime' több mint 2/3-a elszíneződött, segítséget kell kérni és cserélni kell;

- a páracsapdákat is folyamatosan ellenórizni kell amennyiben több, mint félig megteltek, segítséget kell hívni, és cserélni kell;

- a légzőkörben lévő lecsapódott párát folyamatosan üríteni kell - ez esetben a gépről való dekonnekció szabályait kell alkalmazni; 
- amennyiben a HEPA/HME filterek átnedvesedtek, cserélni kell óket a dekonnekció szabályai szerint;

- a frissgáz-áramlást a percventiláció másfélszeresére kell állítani;

- az altatógépek általában nem kompenzálják a szivárgást, amelyet különösen a térfogat-szabályozott lélegeztetési üzemmódokban kell figyelembe venni. $\mathrm{Az}$ eszköz típusától függően előfordulhat, hogy a PEEP-szint nem lesz állandó. A friss gáz hiánya esetén (a szivárgás nagyobb a friss gáz áramlásánál) a lélegeztetés minősége romlik, és ekkor szükség van a kezelő azonnali beavatkozására (a szivárgás csökkentése, a friss gáz áramlásának növelése). A manuális lélegeztetőballon leválasztása esetén a rendszer a légköri levegőt használja, amely meggátolja a friss gáz alacsony szintjét, és javítja a lélegeztetés rendelkezésre állását. Ennek eredményeként a belégzési oxigénkoncentráció a friss gáz beállított oxigénkoncentrációja és a légköri levegő 21\%-os értéke közötti lesz. Amennyiben magas a friss gáz áramlása, akkor kevesebb környezeti levegő kerül be, és növekszik a belégzési oxigénkoncentráció;

- a $\mathrm{FiO}_{2}$ értékét folyamatosan monitorozni kell amennyiben az eltérés a beállított és a bejuttatott koncentráció között nagyobb, mint 5\%, segítséget kell hívni;

- a gázanalizátor mintavevő csövét folyamatosan csatlakoztatva kell tartani;

- a légzőkörök és -filterek használata nem tér el az intenzív osztályos alkalmazástól;

- a manuális lélegeztetést biztosító ballonnak mindig felfújt állapotban kell lennie, és a légzéssel szinkrón mozognia kell. Szükség szerint az $\mathrm{O}_{2}$-bypass gombbal tölthető. Lehetőség szerint nagy, legalább 3 literes ballont használjunk. A legtöbb altatógép lélegeztetőballonja a gépi lélegeztetés során tartályként funkcionál, és felfogja a kilélegzett gázt. Ezért a lélegeztetőballon a gépi lélegeztetés során mozog. A lélegeztetőballon telítettségi szintjének mindig megfelelőnek kell lennie;

- az altatógéppel magas áramlású vagy magas frekvenciájú kezelés nem lehetséges;

- 48-72 óránként az altatógépeket tesztelni kell: ez a folyamat akár 10 percet is igénybe vehet - ebben az esetben a beteget le kell választani az altatógépről a dekonnekció szabályai szerint, és más módon kell a teszt alatt lélegeztetni;

- előfordulhat, hogy az intenzív ellátásban használt lélegeztetőkészülékek esetében elérhető üzemmódok, mérési értékek, beállítások, múveletek stb. nem állnak rendelkezésre az altatógépeken;

- altatógépek használata esetén tilos a gyógyszerek porlasztása és az aeroszolos kezelés - ha aeroszol vagy egyéb gyógyszer kerül a légutakba, az a készülék meghibásodásához vezethet (például a gázanalizátor helytelen mérései) [20-25].
Anyagi támogatás: A közlemény megírása anyagi támogatásban nem részesült.

Szerzői munkamegosztás: V. T.: A kézirat elkészítése. F. B., V. T., F. Á., B. M., L. I., M. Cs., K. Gy.: A kézirat és az ábrák szerkesztése. J. M., F. B.: A közlemény véleményezése. A cikk végleges változatát valamennyi szerző elolvasta és jóváhagyta.

Érdekeltségek: A szerzóknek nincsenek érdekeltségeik.

\section{Irodalom}

[1] Huang C, Wang Y, Li X, et al. Clinical features of patients infected with 2019 novel coronavirus in Wuhan, China. Lancet 2020; 395(10223): 497-506.

[2] Zhou F, Yu T, Du R, et al. Clinical course and risk factors for mortality of adult inpatients with COVID-19 in Wuhan, China: a retrospective study. Lancet 2020; 395: 1054-1062.

[3] World Health Organization. Clinical management of severe acute respiratory infection (SARI) when COVID-19 disease is suspected: interim guidance, 13 March 2020. WHO, Geneva. Available from: https://apps.who.int/iris/handle/10665/ 331446.

[4] Alhazzani W, Møller MH, Arabi YM, et al. Surviving sepsis campaign: guidelines on the management of critically ill adults with coronavirus disease 2019 (COVID-19). Intensive Care Med. 2020 Mar 28. Doi: 10.1007/s00134-020-06022-5. [Epub ahead of print]

[5] Rhodes A, Evans LE, Alhazzani W, et al. Surviving sepsis campaign: international guidelines for management of sepsis and septic shock: 2016. Intensive Care Med. 2017; 43: 304-377.

[6] Weiss SL, Peters MJ, Alhazzani W, et al. Surviving sepsis campaign: international guidelines for the management of septic shock and sepsis-associated organ dysfunction in children. Pediatr Crit Care Med. 2020; 21: e52-e106.

[7] Cai J, Xu J, Lin D, et al. A case series of children with 2019 novel coronavirus infection: Clinical and epidemiological features. Clin Infect Dis. 2020 Feb 28. Doi: 10.1093/cid/ciaal98. [Epub ahead of print]

[8] Xia W, Shao J, Guo Y, et al. Clinical and CT features in pediatric patients with COVID-19 infection: different points from adults. Pediatr Pulmonol. 2020 Mar 5. Doi: 10.1002/ppul.24718. [Epub ahead of print]

[9] Wei M, Yuan J, Liu Y, et al. Novel coronavirus infection in hospitalized infants under 1 year of age in China. JAMA 2020 Feb 14. Doi: 10.1001/jama.2020.2131. [Epub ahead of print]

[10] Amato MB, Meade MO, Slutsky AS, et al. Driving pressure and survival in the acute respiratory distress syndrome. $\mathrm{N}$ Engl J Med. 2015; 372: 747-755.

[11] Briel M, Meade M, Mercat A, et al. Higher vs lower positive endexpiratory pressure in patients with acute lung injury and acute respiratory distress syndrome: systematic review and meta-analysis. JAMA 2010; 303: 865-873.

[12] Writing Group for the Alveolar Recruitment for Acute Respiratory Distress Syndrome Trial (ART) Investigators; Cavalcanti AB, Suzumura EA, Laranjeira LN, et al. Effect of lung recruitment and titrated positive endexpiratory pressure (PEEP) vs low PEEP on mortality in patients with acute respiratory distress syndrome: a randomized clinical trial. JAMA 2017; 318: 13351345 .

[13] Goligher EC, Kavanagh BP, Rubenfeld GD, et al. Oxygenation response to positive endexpiratory pressure predicts mortality in acute respiratory distress syndrome. A secondary analysis of the LOVS and ExPress trials. Am J Respir Crit Care Med. 2014; 190: 70-76. 
[14] Gattinoni L, Collino F, Maiolo G, et al. Positive end-expiratory pressure: how to set it at the individual level. Ann Transl Med. 2017; 5(14): 288 .

[15] Papazian L, Forel JM, Gacouin A, et al. Neuromuscular blockers in early acute respiratory distress syndrome. $\mathrm{N}$ Engl J Med. 2010; 363: 1107-1116.

[16] National Heart, Lung, and Blood Institute, PETAL Clinical Trials Network; Moss M, Huang DT, Brower RG, et al. Early neuromuscular blockade in the acute respiratory distress syndrome. N Engl J Med. 2019; 380: 1997-2008.

[17] Rochwerg B, Brochard L, Elliott MW, et al. Official ERS/ATS clinical practice guidelines: noninvasive ventilation for acute respiratory failure. Eur Respir J. 2017; 50(2): 1602426.

[18] Lansbury L, Rodrigo C, Leonardi-Bee J, et al. Corticosteroids as adjunctive therapy in the treatment of influenza. Cochrane Database Syst Rev. 2016; 2: CD010406.

[19] Delaney JW, Pinto R, Long J, et al. The influence of corticosteroid treatment on the outcome of influenza A(HINlpdm09)related critical illness. Crit Care 2016; 20: 75.

[20] Jain RK, Swaminathan S. Anaesthesia ventilators. Indian J Anaesth. 2013; 57: 525-532.
[21] Jaber S, Langlais N, Fumagalli B, et al. Performance studies of 6 new anesthesia ventilators: bench tests. [Etude des performances de six nouveaux ventilateurs d'anesthésie: banc d'essai.] Ann Fr Anesth Reanim. 2000; 19: 16-22. [French]

[22] Jaber S, Tassaux D, Sebbane M, et al. Performance characteristics of five new anesthesia ventilators and four intensive care ventilators in pressure-support mode: a comparative bench study. Anesthesiology 2006; 105: 944-952.

[23] Sen AC, Kavya KR, Meghna P, et al. Anesthesia workstation versus intensive care ventilator in pediatric cardiac surgery, is there a difference? EC Pulmonol Respir Med. 2019; 86: 522-528.

[24] Bristle T, Collins SB, Hewer I, et al. Anesthesia and critical care ventilator modes: past, present, and future. AANA J. 2014; 82: 387-400.

[25] Dräger. The anesthesia ventilator. Lübeck, 2010. Available from: https://www.draeger.com/Library/Content/9049447_the_ anesthesia_ventilator_8seitig_en_101209_fin.pdf.

(Végh Tamás dr., Debrecen, Nagyerdei krt. 98., 4032 e-mail: veghdr@gmail.com)

A cikk a Creative Commons Attribution 4.0 International License (https://creativecommons.org/licenses/by/4.0/) feltételei szerint publikált Open Access közlemény, melynek szellemében a cikk bármilyen médiumban szabadon felhasználható, megosztható és újraközölhető, feltéve, hogy az eredeti szerzỏ és a közlés helye, illetve a CC License linkje és az esetlegesen végrehajtott módositások feltüntetésre kerülnek. (SID_1) 